\title{
Sentinel Health Unit Surveillance System
}

\author{
CATHY ANDERSON RN MSC
}

$\mathrm{T}$ he Canadian public health system is COnStantly challenged to develop disease prevention and control strategies for Canada. These strategies need to be developed using Canadian population-based data collected on the incidence of and the risk factors associated with selected diseases. Surveillance data can be used to determine the need for public health action, as well as to assess the effectiveness of public health strategies. The information gathered through epidemiological surveillance should be used for planning, implementing and evaluating public health programs (1).

National surveillance activities in Canada are primarily focused on the 45 notifiable diseases for which the Bureau of Communicable Disease Epidemiology, Laboratory Centre for Disease Control (LCDC), receives information monthly from provinces and territories. Information given for these diseases includes numbers of cases and a breakdown by sex and age group (2). Detailed information on individual cases is received from six provinces and the territories. Administrative data sets collected by Statistics Canada, hospital discharge databases (HMRI and Med ECHO), provincial cancer registries, etc, have provided information on other diseases and health conditions. Information from all these sources has limitations in that its format, quality and/or timeliness may not be sufficient for national surveillance needs.

Sentinel systems used for surveillance are an effective public health tool, which has been used in other countries and has proven useful in the monitoring of many diseases (3). In Canada, sentinel physicians have been used in some provinces to monitor influenza ac-

Sentinel Health Unit Surveillance System, Laboratory Centre for Disease Control, Health Canada. Ottawa, Ontario

Correspondence and reprints: Ms Cathy Anderson,

Department of Community Health and Epidemiology.

University of Saskatchewan, Saskatoon. Saskatchewan S7N

ow0. Telephone (306) 966-7943, Fax (306) 966-7920 tivity. Sentinel networks, linking participating organizations to centralized data collection, have been particularly helpful in monitoring specific targeted diseases or disease groups. One such network in use in Canada is the IMPACT System, a hospital-based active surveillance system for monitoring adverse events following immunization.

LCDC, recognizing the need for a public health network for targeted surveillance, recently established the Sentinel Health Unit Surveillance System. This system was designed as a flexible surveillance method to address the need for specific information on targeted diseases. The goal of this community-based system is to provide reliable demographic, risk factor and other epidemiological and laboratory data necessary for the development of strong public health policy.

The Sentinel Health Unit Surveillance System is designed to:

- collect information that will help define key public health issues and will assist in the development of appropriate prevention/control strategies at both provincial and national levels:

- assist in the monitoring and evaluation of current prevention/control strategies; and

- encourage the development of a public health network that includes epidemiological and laboratory expertise.

\section{SENTINEL SITES}

Provincial epidemiologists were asked to identify health units potentially interested in participating in this system. The goal was to identify health units where the residents were likely to seek all of their health care within the health unit jurisdiction. Nine health units in eight provinces are participating in the system (Figure 1). These units represent approximately $10 \%$ of the Canadian population and are a mixture of urban and 
TABLE 1

Summary of participating health units

\begin{tabular}{|c|c|c|}
\hline Health unit & Geographic area & Population \\
\hline $\begin{array}{l}\text { South Okanagan } \\
\text { Health Unit }\end{array}$ & $\begin{array}{l}\text { Kelowna and } \\
\text { surrounding area }\end{array}$ & 178,500 \\
\hline $\begin{array}{l}\text { Edmonton Board of } \\
\text { Health }\end{array}$ & City of Edmonton & 626,000 \\
\hline $\begin{array}{l}\text { Saskatoon Community } \\
\text { Health Unit }\end{array}$ & City of Saskatoon & 187,000 \\
\hline $\begin{array}{l}\text { City of Winnipeg Health } \\
\text { Department }\end{array}$ & Winnipeg inner city & 240,000 \\
\hline $\begin{array}{l}\text { Kingston/Frontenac/ } \\
\text { Lennox and Addington } \\
\text { Health Unit }\end{array}$ & $\begin{array}{l}\text { Kingston and } \\
\text { surrounding area }\end{array}$ & 166,300 \\
\hline $\begin{array}{l}\text { Wellington, Dufferin, } \\
\text { Guelph Health Unit }\end{array}$ & $\begin{array}{l}\text { Guelph and } \\
\text { surrounding area }\end{array}$ & 199,500 \\
\hline $\begin{array}{l}\text { Équipe régionale de } \\
\text { Santé Publique de } \\
\text { I'Estrie }\end{array}$ & $\begin{array}{l}\text { Sherbrooke and } \\
\text { surrounding area }\end{array}$ & 268,400 \\
\hline $\begin{array}{l}\text { Prince Edward Island } \\
\text { Department of Health } \\
\text { and Social Services }\end{array}$ & $\begin{array}{l}\text { Province of Prince } \\
\text { Edward Island }\end{array}$ & 130,500 \\
\hline Halifax & $\begin{array}{l}\text { Halifax and } \\
\text { surrounding area }\end{array}$ & 360,000 \\
\hline
\end{tabular}

rural communities. Although the health units may not be fully representative of the Canadian population, efforts have been made to ensure all major population groups are represented. Four of the health units are located in metropolitan centres having populations greater than 180,000, while the remaining units are in smaller urban and rural communities (Table 1).

\section{ORGANIZATION}

The Sentinel Health Unit Surveillance System depends on active collaboration among the provincial ministries of health, the participating health units, and Health Canada, as well as with other key community participants. Provincial epidemiologists (members of the Advisory Committee on Epidemiology), provincial laboratory directors (members of the Technical Advisory Committee), representatives from each of the sentinel health units and staff from the bureaus of Communicable Disease Epidemiology, Chronic Disease Epidemiology and Microbiology, respectively, of LCDC, participate in the planning and development of the system's activities.

An advisory committee, with representation from the above groups as well as community groups, is being developed. This committee will establish the overall direction for the system, and will oversee the identification and development of projects. Each health unit is also responsible for establishing a local advisory group.

A coordinator located in the Bureau of Communicable Disease Epidemiology acts as the liaison to the participating health units, advisory and expert committees, and staff of LCDC. Negotiations are underway to establish site coordinators in each of the participating

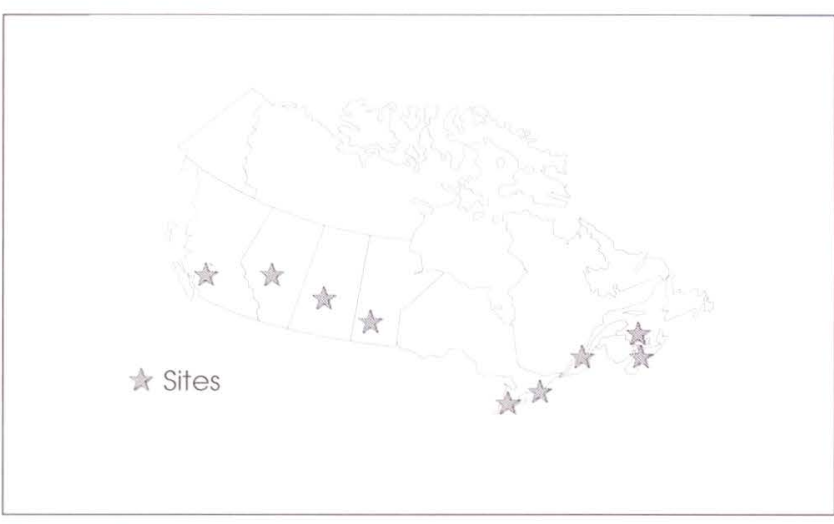

Figure 1) Sentinel health unit sites as of August 1994

health units. These coordinators will provide the local coordination and support to the network.

To facilitate communications among key players and the sentinel sites, a regular newsletter is being planned. As well, each of the sites has been connected to an electronic conference on LCDC's Health Information Network (4). This will allow ready communication of ideas and issues among the sites. This infrastructure will create a sentinel public health network that can be responsive to Canadian needs.

\section{PROJECT SELECTION AND DEVELOPMENT}

Proposed projects will be reviewed by the advisory committee. If the project is considered appropriate and timely, a working group will be identified with specific expertise in the area under consideration. This group is responsible for the identification of the study question, the development of the study design, and determination of the epidemiological and laboratory methods to be used in the study. The protocol will be referred back to the advisory committee for final approval.

The Sentinel Health Unit Surveillance System is currently carrying out targeted surveillance for viral hepatitis (A, B and C). Questionnaires are administered to each eligible case and a blood specimen is forwarded to the Bureau of Microbiology for further laboratory analysis. The goals of this project are to determine the incidence of and risk factors for viral hepatitis, to determine personal and economic costs of the disease and to evaluate current control measures. Information from this study will assist in the development of national control guidelines.

Other projects under development include a schoolbased survey of asthma in school-aged children. Approximately 3000 children (with their parents) in each health unit will be surveyed to determine whether they have ever been diagnosed with asthma. Those who report a history of asthma will be asked to participate in a more in-depth face to face interview. Data collected from this enhanced surveillance will cover prevalence, incidence, severity, treatment and use of health services and will supplement data obtained from the 
National Population Health Survey. A targeted surveillance project for severe respiratory disease in young children is being planned for 1995-96.

\section{SUMMARY}

Public health sentinel surveillance systems are an efficient way to monitor selected diseases/health conditions of Canadians. They can provide data that will build on and complement other surveillance activities. Data generated by the Sentinel Health Unit Surveillance System will contribute both a regional and a national picture of the health of Canadians and an understanding of the role of identified risk factors for acquisition of the disease under study. This information will assist in the development of sound national policies and effective control strategies. For further information on this system, contact Ms Cathy Anderson, Sentinel Health Unit Coordinator, telephone (306) 966-7943, fax (306) 966-7920, Internet Anderson@herald.usask.ca.

\section{REFERENCES}

1. Centers for Disease Control and Prevention. Guidelines for evaluating surveillance systems. MMWR 1988;37(Suppl S-5):1-2.

2. Notifiable disease annual summary 1992. Can Commun Dis Rep 1994;May:20S1.

3. Centers for Disease Control and Prevention. Addressing Emerging Infectious Disease Threats: A Prevention Strategy for the United States. Atlanta: US Department of Health and Human Services, Public Health Service, 1994: 16.

4. Sharpe M. Health Protection Net. Can J Infect Dis $1994 ; 5: 41-2$. 


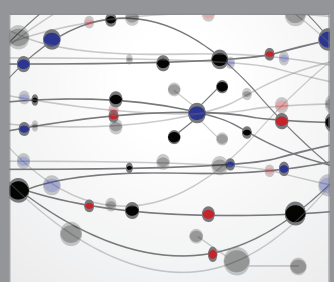

The Scientific World Journal
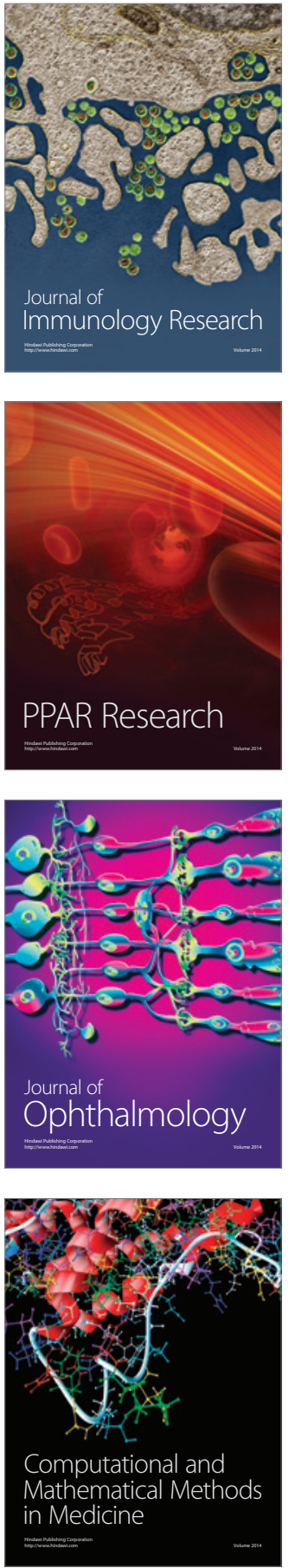

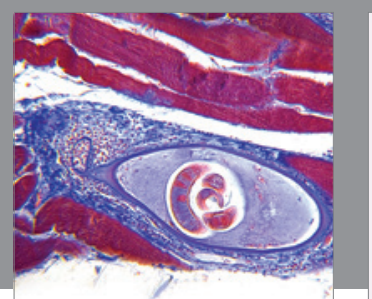

Gastroenterology Research and Practice

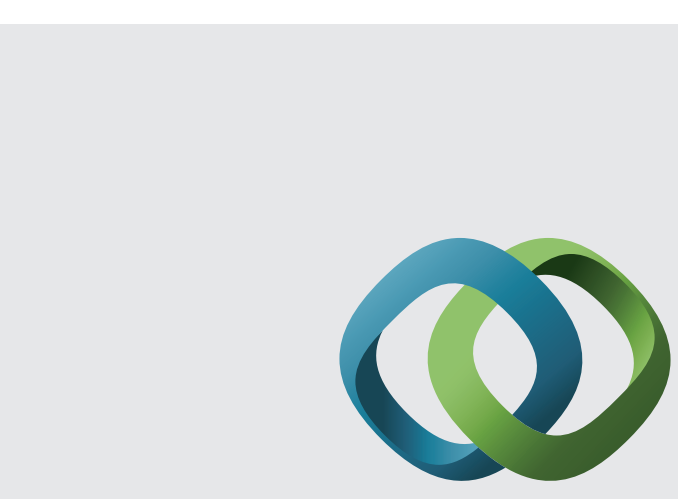

\section{Hindawi}

Submit your manuscripts at

http://www.hindawi.com
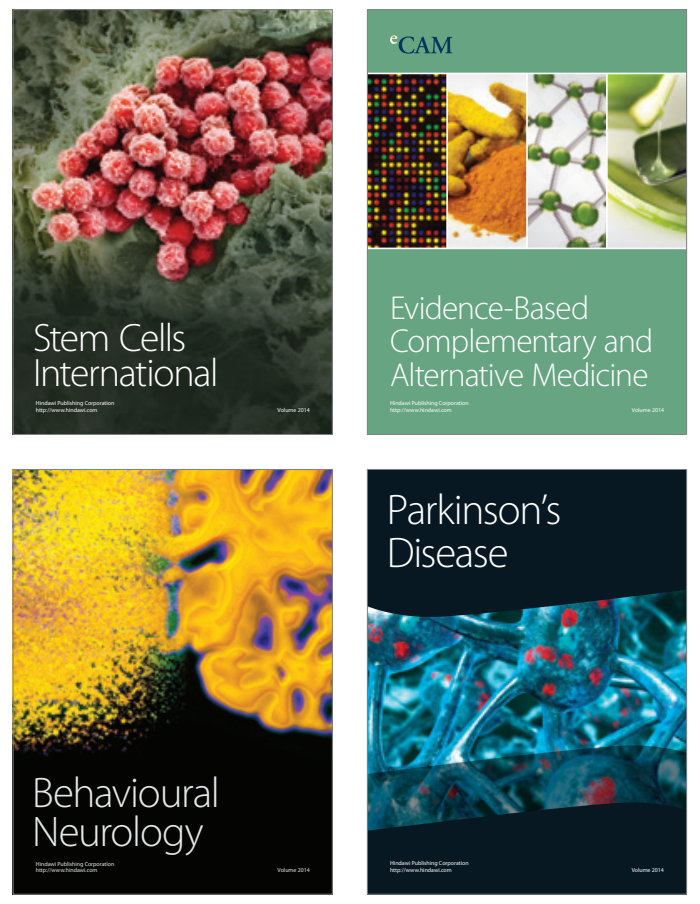
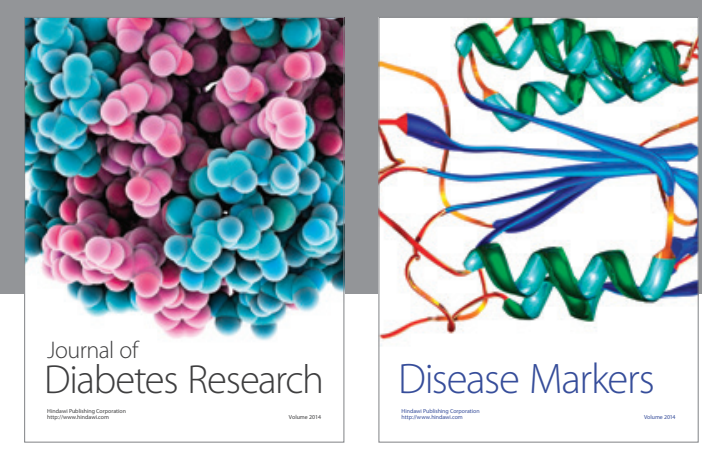

Disease Markers
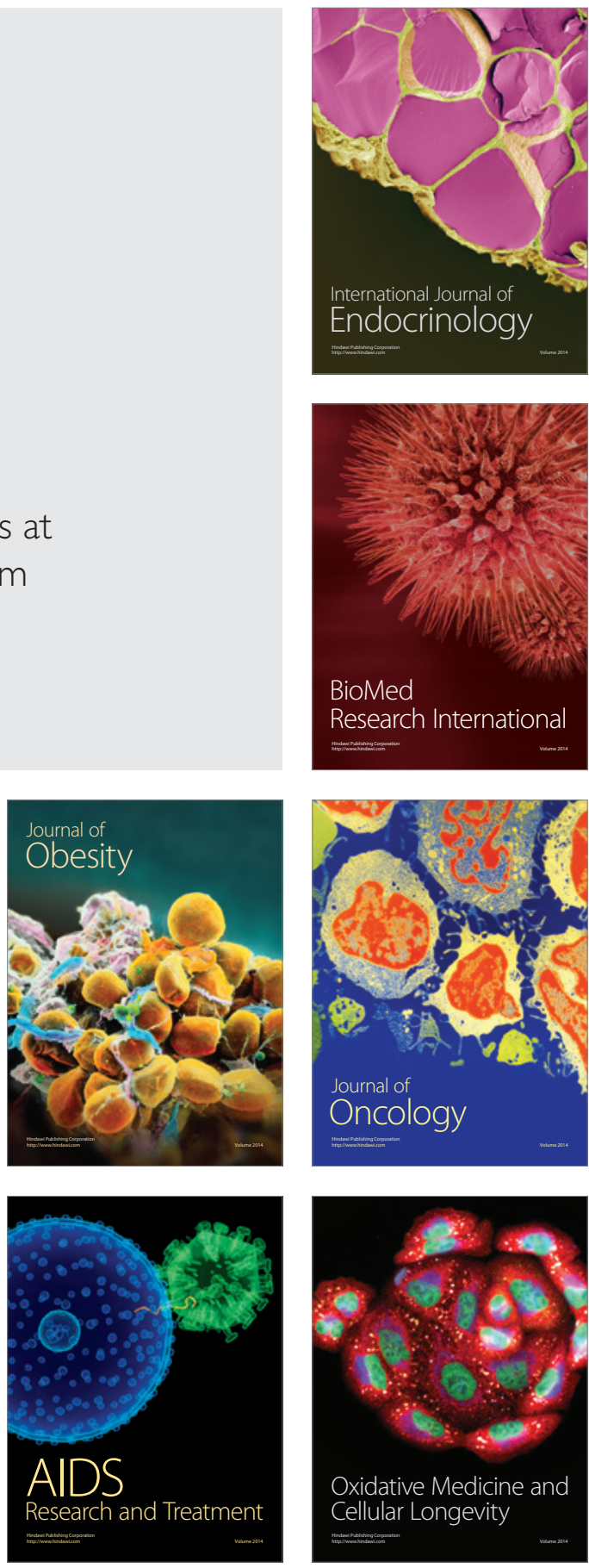